\title{
Hairy Cell Leukemia: Retrospective Analysis of Demographic Data and Outcome of 203 Patients from 12 Medical Centers in Israel
}

\author{
MICHAL INBAR $^{1}$, YAIR HERISHANU ${ }^{2}$, NETA GOLDSCHMIDT ${ }^{3}$, OSNAT BAIREY $^{4}$, MONA YUKLEA $^{5}$, \\ LEV SHVIDEL $^{6}$, RIVA FINEMAN ${ }^{7}$, ARIEL AVIV $^{8}$, ROSA RUCHLEMER $^{9}$, ANDREI BRAESTER ${ }^{10}$, DALLY NAJIB $^{11}$, \\ ORY ROUVIO ${ }^{12}$, ADIR SHAULOV ${ }^{3}$, URI GREENBAUM $^{12}$, AARON POLLIACK $^{3}$ and TAMAR TADMOR ${ }^{1,13}$ \\ ${ }^{1}$ The Ruth and Bruce Rappaport Faculty of Medicine, Technion, Haifa, Israel; \\ ${ }^{2}$ Department of Hematology, Tel-Aviv Sourasky Medical Center and Sackler School of Medicne, \\ Tel-Aviv University, Tel Aviv, Israel; \\ ${ }^{3}$ Department of Hematology, Hadassah University Hospital, Jerusalem, Israel; \\ ${ }^{4}$ Department of Hematology, Rabin Medical Center, Petah-Tikva, Israel; \\ ${ }^{5}$ Department of Hematology, Meir Medical Center, Kfar-Saba, Israel; \\ ${ }^{6}$ Hematology Unit, Kaplan Medical Center, Rehovot, Israel; \\ ${ }^{7}$ Department of Hematology and Bone Marrow Transplantation, Rambam Health Care Campus, Haifa, Israel; \\ ${ }^{8}$ Hematology Unit, Emek Medical Center, Afula, Israel; \\ ${ }^{9}$ Department of Hematology, Shaare Zedek Medical Center, Jerusalem, Israel; \\ ${ }^{10}$ Hematology Unit, Galilee Medical Center, Naharia, Israel; \\ ${ }^{11}$ Hematology Unit, Ziv Medical Center, Zefat, Israel; \\ ${ }^{12}$ Department of Hematology, Soroka University Medical Center, Beer-Sheva, Israel; \\ ${ }^{13}$ Hematology Unit, Bnai-Zion Medical Center, Haifa, Israel
}

\begin{abstract}
Background/Aim: In this retrospective study, we summarized the national Israeli experience with hairy cell leukemia (HCL) in a large cohort of patients with a long followup. Patients and Methods: Demographic data, and relevant laboratory and clinical parameters were analyzed, emphasizing the outcome after first-line treatment with cladribine. Results: Data on 203 patients was collected from 12 medical centers during 1985-2015. Mean and median follow-up were 7.5 years and 5.18 years (interquartile range $=0.1-40$ years), and 5 - and 10 -year survival were $96 \%$ and $90.62 \%$, respectively. The median age of diagnosis was 55.5 years for Jews and 49 years for Arabs ( $p=0.021)$, and most patients were males $(81.77 \%)$; $52.2 \%$ were Ashkenazi Jews, 36.1\% Sephardic Jews and $11.7 \%$ were Arab, Druze or other ethnicity. Cladribine was given to 159 patients $(80.7 \% \%)$ and most (62\%) received intravenous
\end{abstract}

Correspondence to: Dr. Tamar Tadmor, Hematology Unit, BnaiZion Medical Center, 47 Golomb Street, Haifa 31048, Israel. Tel: +972 48359407, Fax: +972 48359962, e-mail: tamar.tadmor@ b-zion.org.il

Key Words: Hairy cell leukemia, HCL, ethnicity, cladribine, intravenous, subcutaneous. (i.v.) and $38 \%$ received subcutaneous (s.c.) therapy. Overall survival and time to next treatment were not significantly different between the two schedules (i.v., s.c.). In univariate analysis of a variety of factors, only age $>65$ years had a negative impact on outcome, with shorter overall survival. It is of interest that Arab patients with HCL were diagnosed at an earlier age, but had a similar clinical course and outcome to both Ashkenazi and Sephardic Jews.

Hairy cell leukemia (HCL) is an uncommon indolent B-cell lymphoproliferative disorder occurring in 3/1,000,000 patients (1). It was first described by Bouroncle et al. in 1958 as "leukemic reticuloendotheliosis"(2) and only later was the term HCL first used describing the characteristic 'hairy' surface features of the leukemia cells. Clinically, the disorder is characterized by pancytopenia, splenomegaly and recurrent infections (3). It is more common in men (4:1 men/women ratio), with a median age at diagnosis of 55 years (4). Diagnosis of HCL is usually made by histopathology after bone marrow biopsy and in combination with a characteristic flow cytometric profile showing $\mathrm{CD} 19^{+}, \mathrm{CD} 20^{+}, \mathrm{CD} 11 \mathrm{c}^{+}$, $\mathrm{CD} 25^{+}, \mathrm{CD}_{103}{ }^{+}, \mathrm{CD}_{123}{ }^{+}, \mathrm{CD} 200^{+}, \mathrm{CD} 27^{-}$, and light chain restriction (3). In 2011, molecular studies by Tiacci et al. showed that almost all cases of HCL were associated with a 
Table I. Demographic, laboratory and clinical data of 180 patients with ethnicity data available.

\begin{tabular}{|c|c|c|c|c|}
\hline Variable & & Jewish $(\mathrm{N}=159)$ & Arab/Druze/Other $(\mathrm{N}=21)$ & $p$-Value \\
\hline Age at diagnosis & Median (range) & $55.5(27-89)$ & $49.0(23-76)$ & 0.021 \\
\hline$\leq 40$ Years & Median $(\%)$ & $22(14 \%)$ & $8(38 \%)$ & 0.005 \\
\hline$>60$ Years & Median (\%) & $56(35 \%)$ & $4(19 \%)$ & 0.13 \\
\hline$>70$ Years & Median $(\%)$ & $24(15 \%)$ & $1(15 \%)$ & 0.2 \\
\hline Gender, $\mathrm{n}(\%)$ & Male & $131(82 \%)$ & $18(86 \%)$ & 0.70 \\
\hline Spleen diameter, $\mathrm{cm}$ & Median (range) & $15(11-35)$ & $16(9.7-30)$ & 0.54 \\
\hline Weight, $\mathrm{kg}$ & Median (range) & $77.0(70-89.5)$ & $82.5(74-93)$ & 0.40 \\
\hline $\mathrm{WBC} \times 10^{9} / 1^{*}$ & Median (range) & $3.0(0.5-29)$ & $3.0(1.45-13)$ & 0.72 \\
\hline $\mathrm{ANC} \times 10^{9} / 1^{*}$ & Median (range) & $0.9(0.1-6)$ & $1.0(0.2-2.6)$ & 0.76 \\
\hline $\mathrm{Hb} \mathrm{g} / \mathrm{dl} *$ & Median (range) & $11.3(5.3-16.5)$ & $11.9(6.8-15.4)$ & 0.39 \\
\hline Platelets $\times 10^{9} / 1^{*}$ & Median (range) & $67(47-90)$ & $61.5(37.5-81)$ & 0.34 \\
\hline \multirow[t]{4}{*}{ Cladribine treatment } & Median course (range), days & $5.0(1-9)$ & $5.0(1-7)$ & 0.53 \\
\hline & Route: i.v. $\mathrm{n}(\%)$ & $62(65 \%)$ & $11(61 \%)$ & \\
\hline & Median total dose (range), $\mathrm{mg}$ & $50.0(27-80)$ & $50.0(40-65)$ & 0.72 \\
\hline & Relapse, n (\%) & $30(29 \%)$ & $4(22 \%)$ & \\
\hline Death, n (\%) & & $13(9 \%)$ & $1(5 \%)$ & 0.57 \\
\hline
\end{tabular}

WBC: White blood cells, ANC: absolute neutrophil count, Hb: hemoglobin, i.v.: intravenous. *On first day of therapy.

point mutation in the signaling protein B-Raf proto-oncogene, serine/threonine kinase (BRAF V600E) (5).

Introduction of the purine nucleoside analogs 2deoxycoformycin (pentostatin) (6) and 2-chlorodeoxyadenosine (cladribine) (7) dramatically improved the outcome of HCL, achieving 10 year overall survival (OS) rates close to $90 \%$ (811). Comparative studies showed that pentostatin and cladribine were equally effective $(10,12)$.

Several alternative schedules have been reported for cladribine given subcutaneously (s.c.) or intravenously (i.v.) (13-15). In relation to dosage, the use of a fixed daily dose or weight-based dose for 5 or 7 days or even a once-weekly schedule have been recorded $(14,16-18)$.

Some earlier data regarding Israeli patients with HCL have been reported but these were either single-or twoinstitute experiences (19-21). In 2006, Paltiel et al. summarized HCL in association with second cancer, based on the statistics obtained from the Israeli Cancer Registry, emphasizing demographic characteristics but without details of therapy administered (20).

Here, we provide a retrospective analysis of the national Israeli experience with HCL during a 30-year period (19852015), which also includes results of first-line therapy with cladribine.

\section{Patients and Methods}

A review was carried out of data obtained from the records of 203 patients with HCL treated at 12 medical centers in Israel during 1985-2015 and related clinical and demographic features with special emphasis on ethnicity (Ashkenazi and Sephardic Jews, Arabs or other) were summarized.
Diagnosis was based on histopathology reports, reported according to WHO criteria (22) and flow cytometric analysis of peripheral blood, bone marrow and spleen specimens.

Details of the treatment given were recorded and outcome after first-line therapy with cladribine given s.c. or i.v. was analyzed. Data regarding outcome were also collected in relation to drug dosage, patient age, ethnicity and gender. All the above were collected after approval by local institutional review board of each medical center included in the study and in accordance with the principles of the declaration of Helsinki.

Statistical analysis. Descriptive statistics were calculated for each of the variables. Data are expressed as the mean \pm standard deviation (SD) (normally distributed data), median and interquartile range (IQR) (non-normally distributed data), or as percentage frequencies.

The Kaplan-Meier method was used to compute product-limit estimates of the survival distribution function of time to next treatment and overall survival (OS) for each selected diagnostic factors.

For OS, the day of diagnosis was used as the starting date for analysis; and for PFS and time to next treatment with cladribine, the first day of treatment was regarded as the starting date of the analysis. The log-rank test was used to compare the survival curves of the different strata.

Univariate analysis was performed to detect differences among selected variables. The Pearson chi-square test or Fisher exact was used to compare the groups with respect to categorical variables. Two sample t-test was employed to compare groups with respect to variables which followed a normal distribution. Two-sample Wilcoxon tests were used to compare groups with respect to variables which did not follow a normal distribution. The association between two continuous variables was evaluated by Pearson correlation coefficient. Statistical significance was defined as a $p$-value of less than 0.05 .

Statistical analysis was performed by SAS for Windows version 9.4. 
A

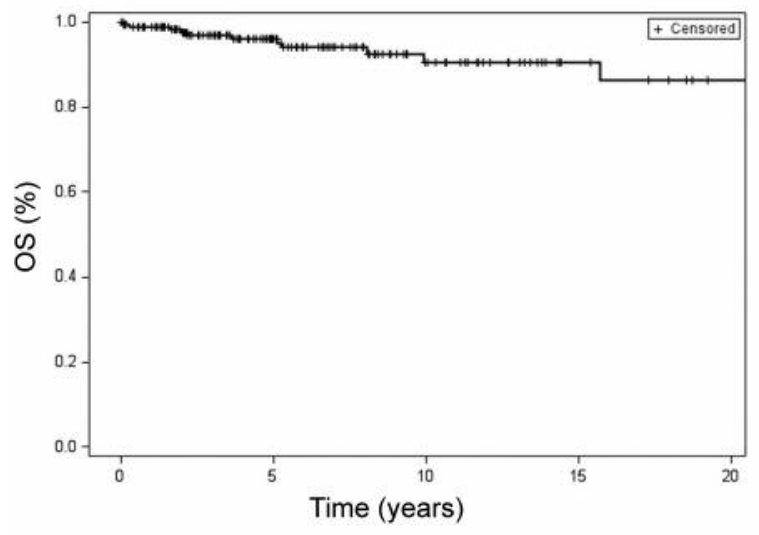

B

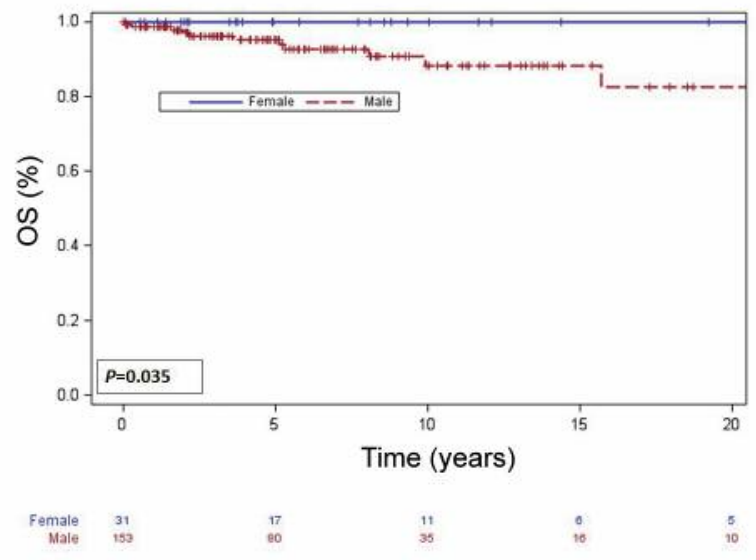

Figure 1. Overall survival (OS) of the entire cohort (A) and based on sex (B).

A

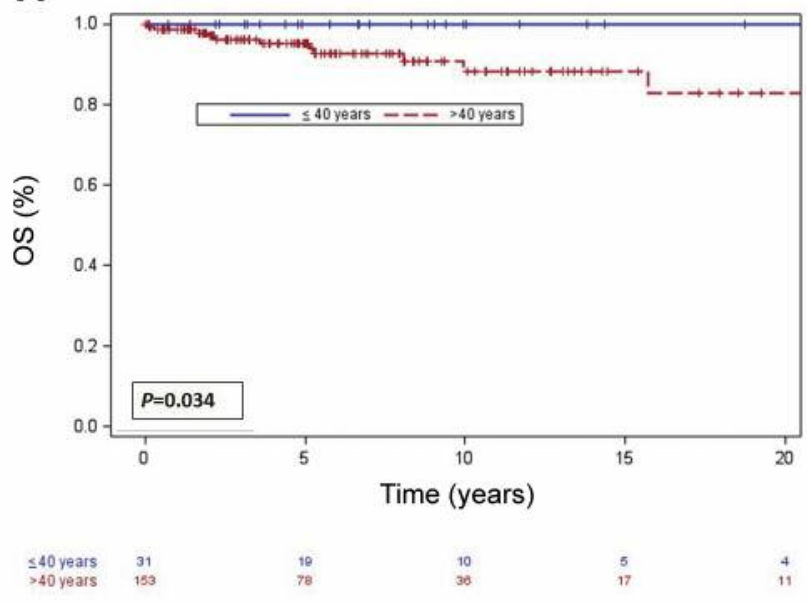

B

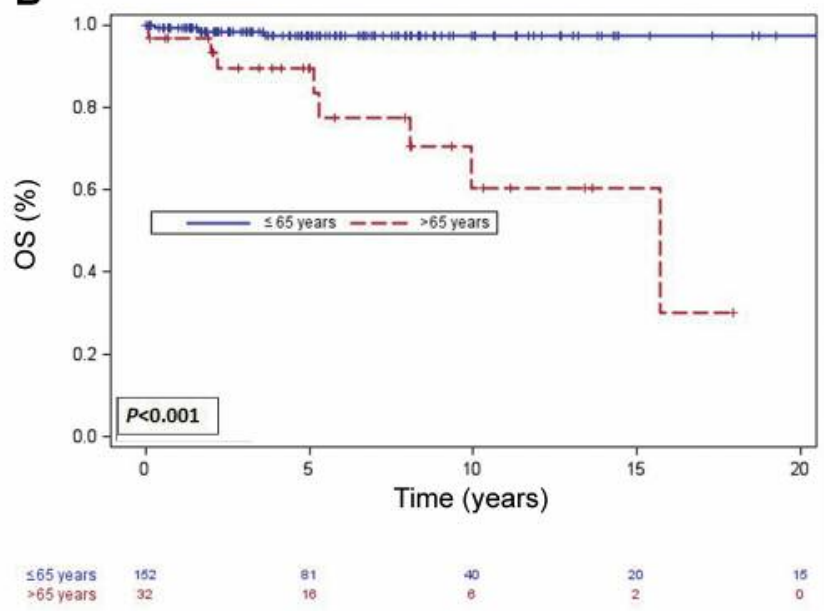

Figure 2. Overall survival (OS) analysis based on age of diagnosis of hairy cell leukemia using cut-offs of 40 (A) and 65 years (B).

\section{Results}

The cohort included 203 patients: $166(81.8 \%)$ males and 37 (18.2\%) females (M; F ratio of 4.5:1). Mean and median follow-up of the entire cohort were 7.5 and $5.18(\mathrm{IQR}=0.1-40)$ years, respectively. Basic patient data are given in Table I.

All cohort survival analysis. OS at 10 and 20 years for the entire cohort from the time of diagnosis was $90 \%$ and $86 \%$, respectively. The 10-year OS after first-line therapy was $94 \%$, and after 20 years was $75 \%$ (Figure 1A). During follow-up, 16 patients died and all were males. Median OS for males was 31.5 years, while it was not reached for females (Figure 1B).
HCL relapse was evident in $40 / 143$ patients (28\%); data were lacking in 16 patients.

Age analysis. Mean age at diagnosis was 54.3 years (IQR=23-89 years), 32 patients $(15.8 \%)$ were 40 years old or younger, and $170(84.2 \%)$ were older than 40 years; 38 patients $(18.8 \%)$ were diagnosed above the age of 65 years.

Patients $\leq 40$ years old had an excellent outcome, and survival was significantly better than in those $>40$ years (Figure 2A, Table II). The Kaplan-Meier estimates of 10and 20-year survival rates after diagnosis (Figure 2A) were $100 \%$ and $100 \%$ for patients $\leq 40$ years of age $(n=32)$ and $88 \%$ and $83 \%$ for patients above the age of 40 years $(n=170)$. 


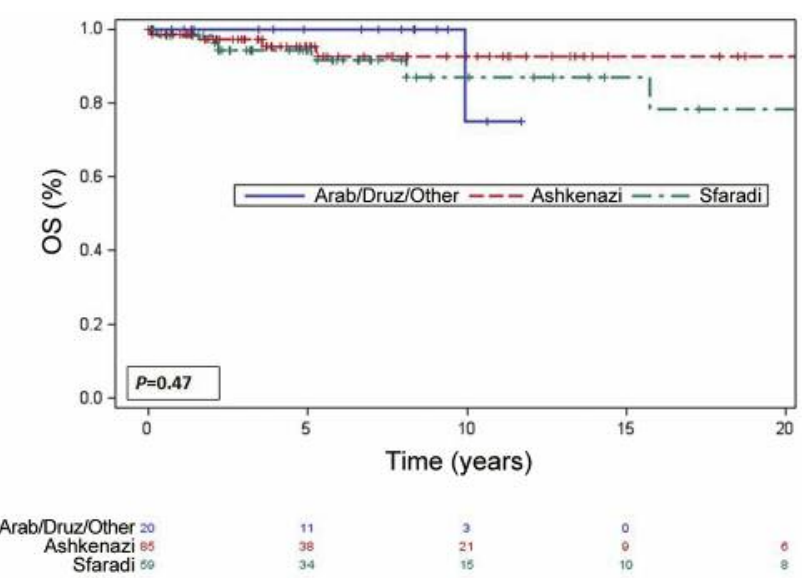

Figure 3. Overall survival (OS) based on ethnicity.

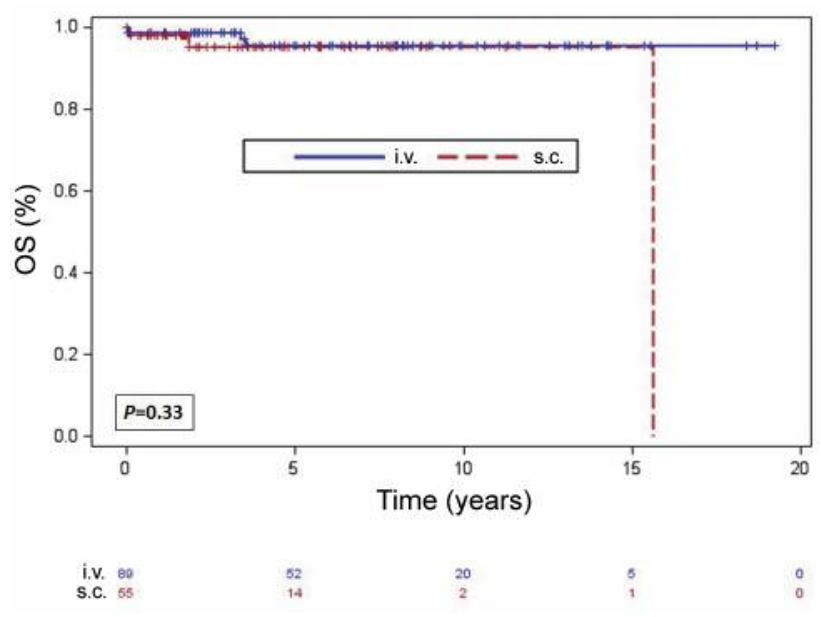

Figure 4. Overall survival (OS) analysis based on mode of cladribine administration. i.v.: Intravenous; s.c.: subcutaneous.

Table II. Demographic, clinical and laboratory values of patients divided according to age at diagnosis.

\begin{tabular}{|c|c|c|c|c|}
\hline \multicolumn{2}{|l|}{ Variable } & \multirow{2}{*}{$\frac{\leq 40 \text { Years }(\mathrm{N}=32)}{18.0(15.0-19.5)}$} & \multirow{2}{*}{$\frac{>40 \text { Years }(\mathrm{N}=170)}{15.0(13.0-18.0)}$} & \multirow{2}{*}{$\frac{p \text {-Value }}{0.006}$} \\
\hline Spleen diameter, $\mathrm{cm}$ & Median (range) & & & \\
\hline $\mathrm{WBC} \times 10^{9} / 1^{*}$ & Median (range) & $3.6(2.1-7.7)$ & $2.7(1.9-4.1)$ & 0.09 \\
\hline $\mathrm{ANC} \times 10^{9} / 1^{*}$ & Median (range) & $0.9(0.3-1.4)$ & $0.9(0.6-1.3)$ & 0.65 \\
\hline $\mathrm{Hb} \mathrm{g} / \mathrm{dl} *$ & Median (range) & $12.2(9.0-13.7)$ & $11.3(10.0-13.0)$ & 0.64 \\
\hline Platelets $\times 10^{9} / 1^{*}$ & Median (range) & $55.0(37.7-77.0)$ & $68.0(47.0-91.0)$ & 0.027 \\
\hline Gender, n (\%) & Male & $25(78 \%)$ & $140(82 \%)$ & 0.57 \\
\hline Ethnicity: n (\%) & Ashkenazi & $8(27 \%)$ & $86(58 \%)$ & 0.002 \\
\hline Sfaradi & & $14(47 \%)$ & $50(34 \%)$ & \\
\hline Arab/Druze/Other & & $8(27 \%)$ & $13(9 \%)$ & \\
\hline Relapse, n (\%) & & $11(50 \%)$ & $29(24 \%)$ & \\
\hline
\end{tabular}

WBC: White blood cells, ANC: absolute neutrophil count, Hb: hemoglobin. *On first day of therapy.

The Kaplan-Meier survival estimates for 10- and 20-year survival rates after diagnosis (Figure 2B) were $98 \%$ and $98 \%$ for patients aged 65 years or less $(n=164)$ and $60 \%$ and $30 \%$ for those above 65 years $(n=38)$, with median survival of 32.5 and 15.7 years, respectively. The log-rank test revealed a statistically significant difference in survival rates over time for both age strata ( $p=0.034$ and $p<0.001$, respectively).

Ethnicity. Data were available for 180 patients with HCL: $159(88.3 \%)$ Jews and $21(11.7 \%)$ Arabs, Druze or other ethnicity. Of the 159 Jewish patients, 94 (59.1\%) were Ashkenazi and 65 (41.9\%) Sephardi. The median age at diagnosis for Jews was 55.5 (IQR=45.0-63.0) years, and 49 (IQR=37.0-57.0) years for Arabs, $p=0.021 ; 38 \%$ of Arabs were diagnosed at age $<40$ years compared to $14 \%$ of Jews $(p=0.005)$. No other significant clinical or laboratory differences were found between these two cohorts (Tables I and II).

Regarding OS and PFS, there were no statistical differences between Ashkenazi Jews, Sephardic Jews, and Arabs or other ethnicity (Figure 3).

Laboratory and clinical data at the start of therapy. Most of the patients presented with splenomegaly [mean 16.4 (IQR=5-30) $\mathrm{cm}]$; mean patient weight at the start of cladribine treatment was available for all 159 patients and was $80 \mathrm{~kg}$ (IQR=58-118 kg).

Laboratory data on first day of treatment were: Median white blood cell count 2,800 (IQR $=0.500-7,800) \times 10^{9} / 1$, hemoglobin $11.3(\mathrm{IQR}=5.3-16.5) \mathrm{g} / \mathrm{dl}$, platelets 65,000 (36.1$281.0) \times 10^{9} / 1$, and absolute neutrophil count 0.900 (IQR $=0.100$ $1.840) \times 10^{9} / 1$. Additional laboratory data based on ethnicity is presented in Table II. 
Cladribine therapy. A total of 159 patients received cladribine as first-line therapy $(78.71 \%)$; other modalities of treatment including interferon alpha or splenectomy, were utilized as first-line in $21(10.3 \%)$ patients, while $23(11.3 \%)$ were untreated.

The median age at start of therapy was 53.8 years and median time from diagnosis to treatment with cladribine was 10 months (IQR $=0-34$ years).

The average dose of cladribine per patient was $52.5 \mathrm{mg}$ and for all patients this was given as a daily injection, employing a weekly schedule. Average course duration was 5 consecutive days (IQR=1-9 days); correlation between dose administered $(\geq 50 \mathrm{mg}$ or $<50 \mathrm{mg}$ ) and OS revealed a trend for improved survival in favor of the higher dose but this was not statistically significant. (hazard ratio $=0.92, p=0.15$ ).

Overall, $62 \%$ of patients received cladribine i.v. compared to $38 \%$ treated s.c.; PFS and OS were not significantly different for patients treated with i.v. or s.c. therapy (Figure 4).

In univariate analysis, gender, ethnicity, patient weight, and treatment duration (5 or 7 days) had no impact on outcome; however, patients $>60$ years were more likely to have received cladribine s.c. than i.v. (39\% vs. $22 \%, p=0.024)$

Post cladribine therapy follow-up. Infectious complications requiring hospitalization were evident in $50.3 \%$ of treated patients (67\% post i.v. and $37 \%$ post s.c. delivery). The median time in hospital was $8(\mathrm{IQR}=0-45)$ days for both groups $(p=0.55)$.

The average time to nadir for blood counts post cladribine was 24.3 days (IQR $=0-196$ days) for patients overall, with a median of 18 and 20 days for those treated with i.v. and s.c. delivery, respectively $(p=0.33)$. The duration of nadir correlated inversely with hemoglobin levels on the first day of therapy; patients with higher hemoglobin levels had a shorter time to nadir $(\mathrm{r}=-0.18, p=0.027)$. Median time to next treatment after first-line therapy was $9.3(0-15.5)$ years.

\section{Discussion}

HCL is a rare malignancy and studies summarizing clinical and laboratory features of the disease in different countries can still highlight additional aspects of this disease.

This retrospective study represents a summary of the Israeli experience with HCL, with particular emphasis on ethnicity, age and data relating to treatment and outcome over a 30-year period, 1985-2015. Earlier reports from Israel dealt with smaller numbers of patients (19-21) but did not include data on therapy given (20).

The Israeli population is heterogeneous and multi-ethnic, with a $75 \%$ Jewish majority, consisting of new immigrants and Israeli-born Jews. The non-Jewish (mostly Muslim Arab) minority represents approximately $25 \%$ of the entire population.
There are only sparse data relating to the epidemiology of HCL and on prognosis according to different ethnic groups, and it is in this respect the Israeli patient cohort is of interest. Results of this study are similar to those reported in an earlier epidemiological study by Paltiel et al. (20). Both show that the mean age at diagnosis in the Jewish population to be 55 years, similar to that recorded in most other Western countries (3), while the mean age at diagnosis was slightly younger, 49 years, in the Arab population. HCL was also more frequent in Jews ( $88 \%$ of the entire cohort), which is similar to that encountered in chronic lymphocytic leukemia, which is also more common in Ashkenazi Jews (23-25). In this respect a genome-wide association study is indeed still needed to confirm these different ethnicity patterns.

Several reports have dealt with outcome of younger patients with HCL (26-29). Rosenberg et al. reported on 88 younger patients treated with cladribine from the Scripps Clinic HCL database (28), while Getta and co-workers summarized their experience with 63 patients with HCL aged $\leq 40$ years at diagnosis from the US (29). These studies showed that OS was significantly shorter for patients diagnosed above the age of 50 or 60 years, indicating that younger patients with HCL have a better survival even after receiving more lines of therapy. The results we report here are also in keeping with the above studies.

In addition, as in other studies $(7,9,10)$, HCL occurred more frequently in males in our cohort, females with HCL had a better outcome than males treated with cladribine, and during follow-up, none of the female patients died. This observation still needs further validation in a larger study.

Regarding treatment, purine analogs are still recommended as first-line therapy for HCL and both cladribine and pentostatin have similar efficacy $(3,8,10,30$ 32). However, in Israel, only cladribine is available for firstline treatment and accordingly, 159 out of the 203 patients reported here were treated with this agent. Like in other reports, the mode of administration $(13-15,32)$ did not appear to affect results of therapy, and outcome after i.v. and s.c. administration of this agent was similar. All patients reported here were treated with daily administration of cladribine; we have very little experience with the weekly regimen, as reported by the Polish group in 2007 (17). Furthermore, there was a trend towards a lower rate of infection with s.c. use.

This study has obvious limitations, which include its retrospective nature. In addition, the practice of follow-up bone marrow biopsy after 4-6 months of therapy was not uniformly adopted in routine practice in Israel at the time. Thus, as this study covers a period of 30 years, we are unable to provide definitive data on complete response and minimal residual disease. Yet in real world experience, many centers do not repeat bone marrow after first-line therapy, and response assessment is performed based on peripheral 
blood analysis, where a very good response is defined as when recovery of the blood counts is achieved (33).

In summary, we herein report variations in the incidence and prognosis of HCL in Israel, mostly related to gender, age and ethnicity. HCL is less frequently encountered in the Arab population, where it occurs at a younger age, and is more common among Ashkenazi than Sephardic Jews. Additional genetic or genomic-wide association studies are still needed to support the observations reported here regarding ethnicity.

\section{Conflicts of Interest}

The Authors have no conflicts of interest to declare in regard to this study.

\section{References}

1 Tallman MS: Current treatment strategies for patients with hairy cell leukemia. Rev Clin Exp Hematol 6(4): 389-400, 2002.

2 Bouroncle BA, Wiseman BK and Doan CA: Leukemic reticuloendotheliosis; Blood 1(7): 609-630, 1958.

3 Grever MR, Abdel-Wahab O, Andritsos LA, Banerji V, Barrientos J, Blachly JS, Call TG, Catovsky D, Dearden C, Demeter J, Else M, Forconi F, Gozzetti A, Ho AD, Johnston JB, Jones J, Juliusson G, Kraut E, Kreitman RJ, Larratt L, Lauria F, Lozanski G, Montserrat E, Parikh SA, Park JH, Polliack A, Quest GR, Rai KR, Ravandi F, Robak T, Saven A, Seymour JF, Tadmor T, Tallman MS, Tam C, Tiacci E, Troussard X, Zent CS, Zenz T, Zinzani PL and Falini B: Consensus guidelines for the diagnosis and management of patients with classic hairy cell leukemia Blood 129(5): 553-560, 2017.

4 Grever MR: How I treat hairy cell leukemia. Blood 115(1): 2128, 2010.

5 Tiacci E, Trifonov V, Schiavoni G, Holmes A, Kern W, Martelli MP, Pucciarini A, Bigerna B, Pacini R, Wells VA, Sportoletti P, Pettirossi V, Mannucci R, Elliott O, Liso A, Ambrosetti A, Pulsoni A, Forconi F, Trentin L, Semenzato G, Inghirami G, Capponi M, Di Raimondo F, Patti C, Arcaini L, Musto P, Pileri S, Haferlach C, Schnittger S, Pizzolo G, Foà R, Farinelli L, Haferlach T, Pasqualucci L, Rabadan R and Falini B: BRAF mutations in hairy-cell leukemia. N Engl J Med 16;364(24): 2305-2315, 2011

6 Spiers AS, Parekh SJ and Bishop MB: Hairy-cell leukemia: induction of complete remission with pentostatin (2'deoxycoformycin). J Clin Oncol 2(12): 1336-1342, 1984.

7 Saven A and Piro LD: Complete remissions in hairy cell leukemia with 2-chlorodeoxyadenosine after failure with 2'deoxycoformycin. Ann Intern Med 15;119(4): 278-283, 1993.

8 Saven A, Burian C, Koziol JA and Piro LD: Long-term followup of patients with hairy cell leukemia after cladribine treatment. Blood 92;(6): 1918-1926, 1998.

9 Catovsky D, Matutes E, Talavera JG, O'Connor NT, Johnson SA, Emmett E, Corbett L and Swansbury J: Long term results with 2-deoxycoformycin in hairy cell leukemia. Leuk Lymphoma 14(Suppl 1): 109-113, 1994.

10 Dearden CE, Else M and Catovsky D: Long-term results for pentostatin and cladribine treatment of hairy cell leukemia. Leuk Lymphoma 52(Suppl 2): 21-24, 2011.
11 Gidron A and Tallman MS: 2-CdA in the treatment of hairy cell leukemia: a review of long-term follow-up. Leuk Lymphoma 47(11): 2301-2307, 2006.

12 Else M, Ruchlemer R, Osuji N, Del Giudice I, Matutes E, Woodman A, Wotherspoon A, Swansbury J, Dearden C and Catovsky D: Long remissions in hairy cell leukemia with purine analogs: a report of 219 patients with a median follow-up of 12.5 years. Cancer 1;104(11): 2442-2448, 2005.

13 Juliusson G, Heldal D, Hippe E, Hedenus M, Malm C, Wallman K, Stolt CM, Evensen SA, Albertioni $F$ and Tjønnfjord $G$ : Subcutaneous injections of 2-chlorodeoxyadenosine for symptomatic hairy cell leukemia. J Clin Oncol 13(4): 989-995, 1995.

14 Juliusson G, Samuelsson H and Swedish Lymphoma R: Hairy cell leukemia epidemiology, pharmacokinetics of cladribine, and long-term follow-up of subcutaneous therapy. Leuk lymphoma 52(Suppl 2): 46-49, 2011.

15 Khorshid O, Namour AE, El-Gammal MM, Mahmoud TY, Fortpied C, Abdel-Malek R and Ramadan S: Efficacy and Safety of Cladribine: Subcutaneous versus Intravenous Administration in Hairy Cell Leukemia Patients. Mediterr J Hematol Infect Dis 16;7(1): e2015058, 2015.

16 Huynh E, Sigal D and Saven A: Cladribine in the treatment of hairy cell leukemia: initial and subsequent results. Leuk Lymphoma 50(Suppl 1): 12-17, 2009.

17 Robak T, Jamroziak K, Gora-Tybor J, Blonski JZ, Kasznicki M, Dwilewicz-Trojaczek J, Wiater E, Zdunczyk A, Dybowicz J, Dmoszynska A, Wojtaszko M, Zdziarska B, Calbecka M, Kostyra A, Hellmann A, Lewandowski K, Stella-Holowiecka B, Sulek K, Gawronski K, Skotnicki AB, Nowak W, Zawilska K, MolendowiczPortala L, Kloczko J, Sokolowski J, Warzocha K, Seferynska I, Ceglarek B and Konopka L: Cladribine in a weekly versus daily schedule for untreated active hairy cell leukemia: final report from the Polish Adult Leukemia Group (PALG) of a prospective randomized multicenter trial. Blood 109(9): 3672-3675, 2007.

18 Hacioglu S, Bilen Y, Eser A, Gurkan E, Yildirim R, Aydogdu I, Dogu MH, Yilmaz M, Kayikci O, Tombak A, Kuku I, Celebi H, Akay MO, Esen R, Korkmaz S and Keskin A: Multicenter retrospective analysis regarding the clinical manifestations and treatment results in patients with hairy cell leukemia: twentyfour-year Turkish experience in cladribine therapy. Hematol Oncol 33(4): 192-198, 2015.

19 Dann EJ, Gillis S, Rachmilewitz EA, Barak V, Cass Y, Ruchlemer R and Polliack A: Hairy cell leukemia: results of chlorodeoxyadenosine therapy in Jerusalem. Leuk lymphoma 14(Suppl 1): 127-131, 1994.

20 Paltiel O, Adler B, Barchana M and Dann EJ: A populationbased study of hairy cell leukemia in Israel. Eur J Haematol 77(5): 372-377, 2006.

21 Filanovsky K, Yacobi R, Vorst E, Barshack I, Ustaev E, Feldberg E and Shvidel L: Second hematologic malignancies in hairy cell leukemia: report of two patients with dynamic mutations in the BRAF gene. Leuk Lymphoma 56(3): 823-825, 2015.

22 Foucar K FB, Catovsky D and Stein H: Hairy Cell Leukaemia. In: WHO Classification of Tumours of the Haematopoietic and Lymphoid Tissues (4th edn), Swerdlow SH, Campo E, Harris NL, Jaffe ES, Pileri SA, Stein H, Thiele J, Vardiman JW (eds). IARC Press: Lyon, 188-190, 2008.

23 Ruchlemer R and Polliack A: Geography, ethnicity and "roots" in chronic lymphocytic leukemia. Leuk Lymphoma 54(6): 11421150,2013 
24 Divino V, Karve S, Gaughan A, DeKoven M, Gao G, Knopf KB and Lanasa MC: Characteristics and treatment patterns among US patients with hairy cell leukemia: a retrospective claims analysis. J Comp Eff Res 9. doi: 10.2217/cer-2017-0014.

25 Tadmor T and Polliack A: Epidemiology and environmental risk in hairy cell leukemia. Best Pract Res Clin Haematol 28(4): 175179, 2015.

26 Shibayama H, Machii T, Yamaguchi M, Tokumine Y and Kitani T: Early age onset of hairy cell leukemia presenting with leukocytosis. Int J Hematol 64(3-4): 287-290, 1996.

27 Al'-Radi LS, Samoilova RS, Tikhonova L, Diagileva OA, Naumova IN, Kaplanskaia IB and Varlamova EIu: Hairy cell leukemia in young patients. Ter Arkh 80(12): 53-58, 2008.

28 Rosenberg JD, Burian C, Waalen J and Saven A: Clinical characteristics and long-term outcome of young hairy cell leukemia patients treated with cladribine; a single-institution series. Blood 9;123(2): 177-183, 2014.

29 Getta MB, Woo KM, Devlin S, Park JH, Abdel-Wahab O, Saven A, Rai K and Tallman MS: Treatment outcomes and secondary cancer incidence in young patients with hairy cell leukaemia; $\mathrm{Br}$ J Haematol 175(3): 402-409, 2016.

30 Robak T, Blasinska-Morawiec M, Blonski J, Hellmann A, Hałaburda K, Konopka L, Kotlarek-Haus S, Potoczek S, Hansz J, Dmoszyńska A, Urasiński I, Zdziarska B, Dwilewicz-Trojaczek J, Hołowiecki J and Skotnicki AB: 2-chlorodeoxyadenosine (cladribine) in the treatment of hairy cell leukemia and hairy cell leukemia variant: 7-year experience in Poland. Eur J Haematol 62(1): 49-56, 1999.
31 Tallman MS and Polliack A: Historical aspects and milestones in the development of effective treatment for hairy cell leukemia. Leuk Lymphoma 50(Suppl 1): 27-28, 2009.

32 Lauria F, Cencini E and Forconi F: Alternative methods of cladribine administration Leuk Lymphoma 52(S2): 34-37, 2011.

33 Cornet E, Delmer A, Feugier P, Garnache-Ottou F, Ghez D, Leblond V, Levy V, Maloisel F, Re D, Zini JM and Troussard X: French Society of Haematology. Recommendations of the SFH (French Society of Haematology) for the diagnosis, treatment and follow-up of hairy cell leukaemia. Ann Hematol 93(12): 1977-1983, 2014.
Received September 10, 2018

Revised September 18, 2018 Accepted October 8, 2018 